Agrosearch (2007) 9 No. 1\&2 $53-60$

\title{
INCIDENCE AND SEVERITY OF COMMON VIRAL AND FUNGAL DISEASES OF DRY SEASON TOMATO CROP IN A SOUTHERN GUINEA SAVANNAH AGRO- ECOLOGY
}

\author{
Arogundade $^{1}$ O., Balogun ${ }^{1}$ O. S. and Fawole, ${ }^{2}$ O.B. \\ 1 Department of Crop Protection, University of Ilorin, Ilorin, Nigeria \\ 2Department of Agronomy, University of Ilorin, PMB 1515, Nigeria
}

\begin{abstract}
The incidence and severity of common fungal and viral diseases affecting dry season tomato crop were determined on the tomato field of the Teaching and Research farm of the University of Ilorin, situated in the Southern Guinea savannah ecological zone of Nigeria. Seeds were sown in January in the nursery and seedlings were transplanted to the field, in January 2005 and 2006 at the age of 4 weeks. The growth period of tomato was partitioned into three stages viz: seedling/vegetative stage (1), pre-flowering stage (2), and flowering/fruiting stage (3), during which the incidence of fungal, viral or mixed fungal and viral diseases were investigated. The aim was to identify the relative prevalence of the disease categories for each growth stages. The results showed plants in the earliest stage of growth with the lowest rate of infection. Nevertheless, viral disease incidence was the significantly highest (22.7\%) at this stage. The incidence of double infections increased gradually from the second growth stage reaching $29 \%$ in the third stage. Comparatively, infection with virus alone in the third stage was $28.5 \%$, while fungus alone was $0.59 \%$. The highest disease severity was in plants that were mixed infected by the two categories of pathogens. Such plants had significant retardation of growth (height and mean number of leaves/leaflets) and yield attributes such as the number of fruits produced per plant compared to singly infected and apparently healthy plants.
\end{abstract}

Keywords: Disease incidence, dry season, tomato, Southern Guinea savannah ecology

\section{Introduction}

Tomato is any fruit of the numerous cultivated varieties of Lycopersicon esculentum (Mill) that is now cultivated widely throughout the world (Hill and Waller, 1998). Although the plant is perennial, it is grown as annual. The size, shape, colour, flavour, vitamin content, method of growth (which may be erect or sprawling) and resistance to disease vary according to the variety (Villareal, 1992).

Tomatoes are attacked by a wide variety of pests and diseases. Among the insects that destroy tomato plants are flea beetle, aphids, white flies (Daccus sp.), cutworms, fruit worms (Heliothis sp.), and horn worms (Wittwer, 1998). The use of resistant variety and judicious use of short acting pesticides such as malathion and carbaryl (Sevin) can control the insects. Deficiency of calcium causes blossom end rot and can be treated by adding lime to the soil or spraying the leaves with a calcium solution. Maintaining adequate moisture in the soil also controls this disorder (Hill and Waller, 1990).

Tomato cultivation is generally more restricted by diseases than pests in most locations. In recent years, there has been a great increase in smallholder tomato cultivation in Nigeria and other African countries both as food and as cash crops. In some countries after a few good years, 
the crop fails drastically seemingly due to a joint disease/nematode complex, which normally build up partly owing to lack of crop rotation (Hill and Waller, 1990). The major fungal diseases of tomato include leaf mould, Fusarium wilt, target spot or early blight and leaf spots. Some of these diseases are soil borne (Villarreal, 1992).

Septoria leaf spot affects plants at any stage of development (Ohlendorf et al, 2004). Another important fungal disease is powdery mildew caused by Oidium lycopersicum. It is very important to scout for disease and to rogue infected plants as soon as they are detected (Douglas, 2005). Tomato plantations in Nigeria are known to be constantly plagued by virus diseases. While some are prominent in the wet season others are prominent in the dry season under irrigation. The availability of the source of virus, susceptible host and presence of vectors determine the occurrence and the severity of disease. Virus diseases of greenhouse and field tomatoes occasionally cause serious damage and large economic loss (Jiskani, 1993). The most common and important virus diseases of tomatoes in Nigeria include tomato mosaic virus (ToMV, genus Tobamovirus), tomato bunchy top virus (TBTV) and tomato yellows (Simon and Sobulo, 1975). Tomato mosaic and tomato yellows virus diseases are the most serious as they can cause as much as $20-90 \%$ loss in fruit yields (Lana and Adegbola, 1977).

The post-rainy season tomato has always been conceived as capable of bringing higher yields and more returns to the tomato and vegetable grower in this part of Nigeria. This period, however, is also occasioned by high soil temperature and limiting soil moisture status. As noted (Mattews, 1991), environmental conditions such as temperature and light variations, season of the year, nutrition and water supply are known to affect the efficiency of infection in some viralhost interaction and may also affect symptoms development and yield responses. In recent times, random survey have shown some categories of diseases as particularly problematic in the ecological zone where this study was carried out. The objective of this study was to help bridge the gap on dearth of literature on this aspect of tomato production through documenting the incidence and severity of some naturally occurring pathogenic diseases associated with each stage of growth of dry season tomato crop in this part of the country. This is hoped would get growers adequately prepared against such eventualities.

\section{Materials and Methods}

\section{Soil preparation and plant propagation}

Tomato plants were grown on the field between the months of January and April in the years 2005 and 2006 at the Teaching and Research farm of the University of Ilorin for the purpose of evaluating the incidence and severity of common fungal and viral diseases associated with furrow irrigated, dry season crops. In both years, the beds were made manually with the hoe after ploughing and harrowing with tractor-driven equipment. The land was then partitioned into 100 beds each measuring $2 \mathrm{~m} \times 2 \mathrm{~m}$. Seedlings of cultivar Roma were raised under irrigation in the nursery for 30 days before being transplanted to the main beds in two per stand and spaced $25 \mathrm{~cm}$ apart giving the population surveyed as 2077 plants $/ 400 \mathrm{~m}^{2}$. The transplants were watered, by furrow irrigation, twice a week throughout the survey period. NPK (15:15:15) fertilizer was applied by spot placement at the rate of $5 \mathrm{~g} / \mathrm{stand}$ two weeks after transplanting. Manual weeding and staking were done as at when necessary. 
Arogundade, Balogun and Fawole

\section{Data collection}

In both years of the study the growing period of the plant were partitioned into 3 stages. Stage 1 covered the first 4 weeks after transplanting (the main vegetative stage), stage 2 was the period from the $5^{\text {th }}$ week to the $8^{\text {th }}$ week (flowering stage), while stage 3 was from the 9 th to the $12^{\text {th }}$ week (fruiting stage). The fungal and viral diseases were also grouped into 3 categories viz: viral only, fungal only, and mixed fungal and viral infection,

which were also treatments examined under the various stages of growth. Data were collected weekly on the types of diseases that were prevalent during the different growth stages of the plants. Characteristic symptoms were used to identify the category of pathogenic diseases and the actual number of plants infected per bed were recorded as either viral alone, fungal alone, or fungal + viral infected plants. Plants that were identified to exhibit unambiguous foliar symptoms characteristic of fungal or viral infections in the experimental units were tagged for data collection over a 12-week study period on the field. Number of leaves on apparently healthy and visibly diseased plants was counted directly, while height was measured with the use of a tape rule. Simple descriptive statistic was used for the counting and percentage. The percentage infected plants was determined using the formula:

$$
\frac{\text { Number of infected plants/bed }}{\text { Population of plants/bed }} \times \frac{100}{1}
$$

The rate of infection was taken as the stage-wise marginal increase in infected plants i.e. absolute difference between the values of succeeding and preceding stages. The number of leaves, flowers, total number of leaflets and plant height were randomly taken on both apparently healthy and diseased plants to determine the severity of disease in both survey years.

All data were subjected to appropriate analysis of variance. Comparison for all pairs of treatment means were carried out using the New Duncan's multiple range tests at 5\% level of significance.

\section{Laboratory isolation of fungal agents}

Isolation from both roots and leaf samples to confirm presence of associated fungi was carried out using standard methods. Plant samples were chopped up using flame-sterilized scalpel. The materials were surface-sterilized in $0.5 \%$ chlorox and rinsed properly with sterile distilled water. They were blotted dry between sterile Whatman no. 3 filter paper before plating on PDA. The identification up to generic level was carried out using both colony and microscopic characteristics (Barnett, 1960; Doran, 1980).

\section{Results and Discussion}

Plate 1 shows plants manifesting different symptoms because of infection with different pathogens. Plants infected with leaf curl disease of tomato manifested characteristic symptoms of curled, twisted leaves and cessation of growth of the terminal ends. Those affected with mosaic virus showed conspicuous mosaic symptoms i.e. the leaves of the affected plants showed a pattern of light and dark green areas. The plants infected with either of the viral diseases were typically retarded in growth. Many plants show a typical mosaic/leaf curl symptoms. 
A few cases of powdery mildew caused mainly by Oidium lycopersici was also observed during the course of the survey. The infected plants were covered with a white powdery appearance on their stems and leaves. Alternarial blight was also prevalent on plants. The characteristic symptom was also confirmed by laboratory testing. Meanwhile, the most extreme symptomatic response of fungal infection was wilting and eventual dying off. Such characteristic symptoms due to root rot infections could have been caused by Rhizoctonia, Fusarium, Pythium, Sclerotium and Verticillium.
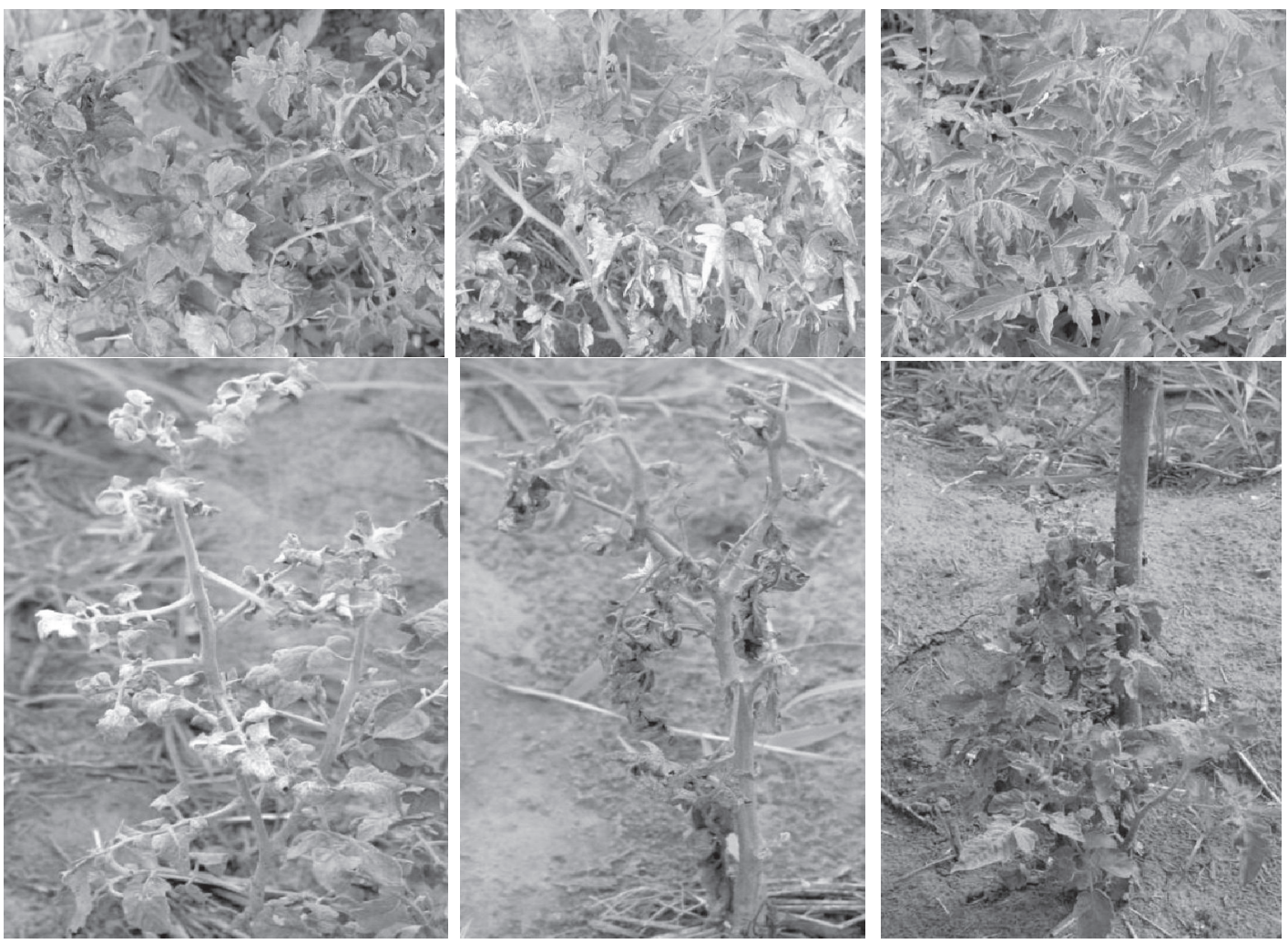

Plate 1: Selected symptoms manifested on dry season tomato under natural infection of different fungal and viral pathogens in the Southern Guinea savannah Agro-ecology of Nigeria

Upper row from left: Leaf curl/mosaic (viral); Middle: Alternaria leaf blight (fungal) and apparently healthy plant (right).

Lower row from left: Powdery mildew (fungal); Middle: dieback (soil borne fungal pathogen) and severe stunting. (fungal/viral mixed infection).

Laboratory isolation and identification of associated pathogenic agents from root samples, however, showed that Verticillium dahliae and Pythium aphanidermatum were the most prevalent. In Previous studies, Balogun et al $(2005,2006)$ had also identified Verticillium 
spp isolated from field pepper in the study area, as particularly problematic in rain -fed pepper and tomato.

\section{Incidence of disease}

The data for 2005 and 2006 followed the same pattern. As shown in Table 1, there were significant differences in the incidence of fungal and viral infection as well as mixed infection during the early seedling and early flowering stages of growth in 2005. Incidence of Viral infection and mixed fungal and viral infection was generally on the increase with time after transplanting.

Table 2 shows a progressive decrease in the percentage of the single infections and a proportionate increase in mixed infection over time. Whereas fungus alone was $2.1 \%$ in the $6^{\text {th }}$ week it fell to $0.59 \%$ in the $10^{\text {th }}$ week. Virus alone was $30.1 \%$ in the $6^{\text {th }}$ week but

$28.6 \%$ in the $10^{\text {th }}$ week. Percentage incidence of mixed infection was $4.4 \%$ in the $6^{\text {th }}$ week but the figure rose to $29.8 \%$ in the $10^{\text {th }}$ week at the fruiting stage.

\section{Percentage marginal incidence}

Table 3 shows marginal incidence of diseases (pathogen-wise) in dry season tomato during the 3 stages of growth. As shown in the table, virus alone was highest in stage 1 of growth of tomato $(22.7 \%)$ while the lowest incidence was fungal infection only. The trend was the same for stage 2 . In fact, the negative value indicates a decrease in incidence. During the third stage of growth, mixed infection incidence was highest.

Irrespective of the pathogens that caused the disease, significant differences were observed among the three stages of growth as regards the rate of infection of plants. Stage 1 had the lowest mixed infection rate while stage 3 had the highest obviously because of gradual super infection of hitherto viral infected plants by fungi..

From Table 3, viral disease alone, as well as mixed pathogen disease (i.e. fungus + virus) was the most prevalent at the end of the survey with a cumulative value of $28.5 \%$ and $29.9 \%$ respectively. The incidence of fungal leaf spot alone was the lowest $0.59 \%$.

\section{Selected growth parameters in healthy and diseased plants}

Table 4 shows the significant differences that exist in growth and yield parameters between the healthy and diseased plants as measured at 12 weeks after transplanting. The table shows that the average height of healthy plant was $68.8 \mathrm{~cm}$ while that of diseased plant was $46.2 \mathrm{~cm}$. Considering leaf production, the average number of leaflets per plant was 259.5 in healthy plants while that of diseased plant was 137.3. The average number of leaves for healthy plants was 56.3 while that of diseased plant was 25.0.

The results put together showed that dry season tomato plants at the three stages of growth were susceptible to both fungal and viral attacks. Stage 1 (i.e. the seedling /vegetative stage from day 1 to $28^{\text {th }}$ day after transplanting) was discovered to have the highest rate of single viral disease infection. This might be due to the fact that leaf curl, which is the prevalent viral disease, is the most serious disease of tomato in the dry season under irrigation. The tender nature of the plant at this early stage coupled with the fact that white fly vectors were abundant at that time could be responsible for the significantly higher rate of infection of plants. The highest percentage of mixed infection with both fungus and virus was in the third stage .i.e. between 9th 
and $12^{\text {th }}$ week. At this stage, the percentage of aggravated fungal diseases on plants already infected by virus increased dramatically. This trend could be as a result of the on coming of rainy season at that time (around March). Hence, the fungal spores were more abundant at that time as a result of the warm wet condition in Ilorin area during the time of this study. Following double infections, such plants were the most retarded in growth. Mixed infection with pathogens is known to cause more repression of growth and yield than single infection in tomato (Balogun et al., 2002; Balogun, 2003).

The results of this study suggest that viral diseases should be taken seriously during dry season tomato cultivation. Although it was not part of this study to undertake insect occurrence studies, observations on white flies during the study period showed considerable populations. It would appear therefore that significant control of viral diseases might be achieved by controlling these vectors using appropriate insecticides.

Furthermore, fungicidal treatment at the onset of the rainy season is a necessity if good harvest is to be obtained from dry season tomato in the Southern Guinea savannah ecology of Nigeria.

\section{Acknowledgement}

We sincerely appreciate the efforts of Mr. Enibukun, S.O. of the University of Ilorin Teaching and Research farm for assistance with irrigation facilities and with some aspects of data collection during the study period.

\section{References}

Balogun, S. O., Xu, L., Teraoka, T., And Hosokawa, D. 2002 Effect of single and mixed infections with Potato X potexvirus and Tobacco mosaic tobamovirus on disease, plant growth and accumulation of virus in tomato Fitopatol Bras. 27(3):241-248.

Balogun, O.S. 2003. Patterns of disease manifestation in tomato seedlings, singly or doubly infected with potato $\mathrm{x}$ potexvirus and tobacco mosaic tobamovirus. Biokemistri. 14: 5968.

Balogun, O.S, Odeyemi, G.A. and Fawole, O.B. 2005. Evaluation of the pathogenic effect of some fungal isolates on fruits and seedlings of pepper (Capsicum spp). J. Agric

Res. \& Dev. 4(2) 159-169.

Balogun, O.S, Alade, M.A and Fawole,O.B 2006. Disease development and growth response of tomato plants to infection with a fungal isolate from pepper. J. Agric Res. \& Dev. $5(1): 16-26$.

Barnett, H.L 1960. Illustrated Genera of Imperfecti Fungi. Burges Publishing Company. Minneapolis, Minnesota. 241pp.

Doran, J.W. 1980. Microbial Changes associated with management with reduced tillage. Soil Science Society of American Journal 44: 518-524.

Douglas, S.M. 2005. Powdery Mildew of Tomato. Department of Plant Pathology and Ecology. The Connecticut Agricultural Experimental Station. 
Arogundade, Balogun and Fawole

Hill, D.S and Waller, J.M 1990. Pests and diseases of tropical crops.Longman Scientific and Technical, U.S.A Jiskani, M.M.1993. Plant viruses: Major threat to crops. Plant Dis. 79: 360369.

Lana, A.F., Adegbola, M.O.K. 1977. Important virus diseases in West African Crops. Rev. of Plant Pathol. 56(10): 849-868.

Matthews, R.E.F. 1991. Plant Virology ( ${ }^{\text {rd }}$ Edition). Academic Press Inc., Sandiego.

Ohlendorf, B., Moratorio, B.M and Yao, G.. 2004. Yolo County Master Garden, University of California and USDA. Co-Operating.

Simons, J.N., Sobulo R.A. 1975. Methods for higher tomato yield. Bulletin, Ministry of Agriculture and Natural Resources, Western Nigeria, 10, 26pp.

Villareal, R.L. 1992. Tomatoes in the tropics. West view press, Colorado. pp97, $103-104,111$

Wittwer, S.H 1998. The Encyclopedia Americana International edition, Vol. 26 pp832 - 833.

Table 1: Cumulative Percentage Incidence of Fungal and Viral Diseases During Seedling /Vegetative Stage over the First 5 Weeks after Transplanting in 2005

\begin{tabular}{llllll}
\hline Treatment & Week 1 & Week 2 & Week 3 & Week 4 & Week 5 \\
\hline Fungus alone & $1.5^{\mathrm{b}}$ & $2.1^{\mathrm{b}}$ & $0.77^{\mathrm{c}}$ & $1.7^{\mathrm{c}}$ & $3.3^{\mathrm{c}}$ \\
Virus alone & $4.8^{\mathrm{a}}$ & $13.8^{\mathrm{a}}$ & $21.6^{\mathrm{a}}$ & $22.7^{\mathrm{a}}$ & $21.1^{\mathrm{a}}$ \\
Fungus + virus & $0.2^{\mathrm{c}}$ & $1.1^{\mathrm{b}}$ & $2.4^{\mathrm{b}}$ & $2.7^{\mathrm{b}}$ & $9.0^{\mathrm{b}}$ \\
S. Error & 0.346 & 0.538 & 0.548 & 0.686 & 1.359 \\
\hline
\end{tabular}

Figures in the same column that are followed by different superscripts are significantly different at $\mathrm{P}<0.05$ using New Duncan's multiple range tests.

Table 2: Time-Course Analysis of Cumulative Incidence of Fungal and Viral Diseases at the Mid Flowering and Fruiting Stages in 2005

\begin{tabular}{llllll}
\hline Treatment & Week 6 & Week 7 & Week 8 & Week 9 & Week 10 \\
\hline Fungus alone & $2.1^{\mathrm{c}}$ & $0.8^{\mathrm{c}}$ & $5.7^{\mathrm{c}}$ & $0.52^{\mathrm{b}}$ & $0.59^{\mathrm{c}}$ \\
Virus alone & $30.1^{\mathrm{a}}$ & $30.4^{\mathrm{a}}$ & $29.6^{\mathrm{a}}$ & $28.9^{\mathrm{a}}$ & $28.6^{\mathrm{a}}$ \\
Fungus + virus & $5.4^{\mathrm{b}}$ & $7.5^{\mathrm{b}}$ & $12.4^{\mathrm{b}}$ & $25.6^{\mathrm{a}}$ & $29.8^{\mathrm{a}}$ \\
S. Error & 0.969 & 0.850 & 1.552 & 1.261 & 1.268 \\
\hline
\end{tabular}

Figures in the same column that are followed by different superscripts are significantly different at $\mathrm{P}<0.05$ using New Duncan's multiple range tests.

Table 3: The Marginal and Total Incidence of Pathogenic Diseases at Different Stages of Growth of Dry Season Tomato in 2005.

\begin{tabular}{lllll}
\hline Treatment & Stage 1 & Stage 2 & Stage 3 & \% total Incidence \\
\hline Fungus alone & $1.7^{\mathrm{b}}$ & $-0.92^{\mathrm{c}}$ & $-0.18^{\mathrm{b}}$ & $0.59^{\mathrm{b}}$ \\
Virus alone & $22.7^{\mathrm{a}}$ & $7.8^{\mathrm{a}}$ & $-1.53^{\mathrm{b}}$ & $28.51^{\mathrm{a}}$ \\
Fungus + virus & $2.7^{\mathrm{b}}$ & $4.9^{\mathrm{b}}$ & $22.54^{\mathrm{a}}$ & $29.9^{\mathrm{a}}$ \\
S. Error & 0.686 & 1.203 & 1.134 & 1.273 \\
\hline
\end{tabular}

Means followed by the same superscript in the same column are not significantly different at $\mathrm{P}$ $=0.05$ level of significance. 
Arogundade, Balogun and Fawole

Table 4: Comparative Selected Growth and Yield Parameters in Healthy and Diseased Plants, 2005

\begin{tabular}{lllll}
\hline Treatment & $\begin{array}{c}\text { Mean plant height } \\
(\mathbf{C m})\end{array}$ & $\begin{array}{c}\text { Mean number } \\
\text { of leaflets/plant }\end{array}$ & $\begin{array}{c}\text { Mean } \\
\text { number of } \\
\text { leaves/plant }\end{array}$ & $\begin{array}{c}\text { Total number } \\
\text { of fruits/stand }\end{array}$ \\
\hline Healthy plant & $68.8^{\mathrm{a}}$ & $259.5^{\mathrm{a}}$ & $56.3^{\mathrm{a}}$ & $20.3^{\mathrm{a}}$ \\
Diseased plant & $46.2^{\mathrm{b}}$ & $137.3^{\mathrm{b}}$ & $25.0^{\mathrm{b}}$ & $9.0^{\mathrm{b}}$ \\
S. Error & 4.955 & 25.54 & 6.085 & 1.668 \\
\hline
\end{tabular}

Each value is a mean of 100 plants each. Different superscripts in the same column means they are significantly different at $\mathrm{P}=0.05$ level of significance. 